Jurnal Spektrum Komunikasi Vol. 8 No. 1, Juni 2020

\title{
PENGELOLAAN MEDIA SOSIAL PEACE GENERATION INDONESIA DALAM MENGAMPANYEKAN NILAI-NILAI PERDAMAIAN
}

\section{SOCIAL MEDIA MANAGEMENT PEACE GENERATION INDONESIA IN ORDER TO CAMPAIGN VALUES OF PEACE}

\author{
Resa Rosanti ${ }^{1}$, Feliza Zubair ${ }^{2}$, Aat Ruchiat Nugraha ${ }^{3}$ \\ 1,2,3 Universitas Padjadjaran \\ Email: ruchiat@unpad.ac.id
}

\begin{abstract}
Technological advances are rapidly causing a change in a variety of ways, especially increasing the rapid use of the Internet that can utilize to abuse in the "hastening" situation of social peace. Through the use of social media in the form of Instagram conducted by Peace Generation Indonesia, we strive to know the development of issues and information that occur in the community and as well as the media campaign and dissemination of information messages. The research aims to determine the determination of the situation, goal setting, target audience, strategy, tactics, timelines, and budgets on social media of Peace Generation Indonesia. The method used in this study is qualitative descriptive based on the technique of data collection produced through observations, interviews, and literature studies. The results showed that the determination of the current situation in every area of life in the community is leading to the digital era and many social media accounts are "radical". As for the goal setting is to campaign the values of peace to the public with the target audience is the young urban generation for the strategy that is done by Peace Generation Indonesia, namely community engagement, Agent of Peace (AoP), special event, and social media activation. The tactics used by Peace Generation Indonesia are by identifying problems, discussions, designing messages, and uploading content. The suggestion this research should conduct in-depth research that is more structured about setting target targets, interaction patterns with followers, schedules to upload content on Instagram social media and create budget activities. The research conclusion shows that the stages in Instagram's media management strategy are in line with Regina Luttrell's steps. The advice should be that Peace Generation Indonesia can more specialize in the message target of Perdaiaman campaign.
\end{abstract}

Keywords: Instagram; strategy; social media planning; Peace Generation Indonesia; technology

\begin{abstract}
ABSTRAK
Kemajuan teknologi semakin cepat menyebabkan perubahan dalam berbagai hal, terutama meningkatnya penggunaan internet yang semakin pesat yang dapat dimanfaatkan untuk disalahgunakan dalam "memperkeruh" situasi kedamaian sosial. Melalui penggunan media sosial berupa Instagram yang dilakukan oleh Peace Generation Indonesia, berupaya untuk mengetahui perkembangan isu dan informasi
\end{abstract}

ISSN 2338 - 0861 (cetak); e-ISSN 2621 - 8712 (online)

website : http://spektrum.stikosa-aws.ac.id 
yang terjadi di masyarakat dan sekaligus sebagai media kampanye dan penyebaran informasi pesan-pesan perdaiaman. Penelitian ini bertujuan untuk mengetahui penetapan situasi, penetapan tujuan, target audiens, strategi, taktik, timeline, dan anggaran pada media sosial instagram Peace Generation Indonesia. Adapun metode yang digunakan dalam penelitian ini adalah kualitatif deskriptif berdasarkan teknik pengumpulan data yang dihasilkan melalui observasi, wawancara, dan studi kepustakaan. Hasil penelitian menunjukkan bahwa penetapan situasi yang saat ini disetiap bidang kehidupan di masyarakat sedang mengarah ke era digital dan banyak terdapat akun-akun media sosial yang bersifat "radikal". Adapun pada penetapan tujuan yaitu untuk mengampanyekan nilai-nilai perdamaian kepada publik dengan target sasaran adalah generasi muda yang berada perkotaan. Untuk strategi yang dilakukan oleh Peace Generation Indonesia yaitu community engagement, Agent of Peace (AoP), special event, dan social media activation. Taktik yang digunakan oleh Peace Generation Indonesia adalah dengan cara mengidentifikasi masalah, diskusi, merancang pesan, dan mengunggah konten. Simpulan penelitian menunjukkan bahwa tahapan dalam strategi pengelolaan media Instagram sudah sesuai dengan tahapan yang dikemukan oleh Regina Luttrell. Adapun sarannya adalah sebaiknya Peace Generation Indonesia dapat lebih mengkhususkan sasaran pesan kampanye perdaiaman.

Kata-kata Kunci: Instagram; strategi; perencanaan media sosial; Peace Generation Indonesia; teknologi

\section{PENDAHULUAN}

Perkembangan media sosial
saat ini tidak lepas dari perkembangan teknologi. Hal ini sesuai dengan pernyataan bahwa dengan memiliki karakter yang luas tanpa batas ruang dan waktu serta kemudahan dalam mengakses membuat media sosial semakin memiliki positioning yang utama di masyarakat (Abadi, 2019). Perkembangan teknologi di bidang elektronik telah melahirkan teknologi internet yang memungkinkan dunia menjadi tanpa batas. Perkembangan teknologi informasi komunikasi saat ini semakin memberikan kemudahan bagi masyarakat didalam mendapatkan kebutuhan akan informasi. Salah satu teknologi informasi komunikasi yang semakin banyak digunakan saat ini adalah media sosial Instagram. Keberadaan media sosial sendiri merupakan sebuah alternatif baru bagi para khalayak media dalam menemukan dan mengakses informasi tanpa terhalang ruang dan waktu.

Hal tersebut dibuktikan dengan banyaknya pengguna sosial media di dunia khususnya di Indonesia. Berdasarkan data dari Asosiasi Penyelenggara Jasa Internet Indonesia (APJII) jumlah pengguna internet di Indonesia meningkat 10,12\% pada tahun 2018 lalu. Dari total populasi sebanyak 264 juta jiwa penduduk Indonesia, ada sebanyak 171,17 juta jiwa atau sekitar 64,8 persen yang sudah terhubung ke internet (Kompas, 2019).

Penggunaan media sosial di Indonesia sudah menjadi sebuah pilihan gaya hidup yang lumrah dalam beberapa tahun terakhir. Hal ini membuat Indonesia menjadi negara 
dengan pengguna sosial media Facebook dan Instagram terbesar keempat di dunia. Menurut data riset dari portal diskon online, Cuponation, hingga April 2019 jumlah pengguna media sosial Facebook di Indonesia mencapai 120 juta mengalahkan Meksiko, Filipina, Thailand, Turki, dan Inggris (Tirto, 2019).

\section{Sementara}

pengguna

Instagram di Indonesia mencapai 56 juta pengguna Instagram dengan menempati urutan yang sama seperti pengguna Facebook yaitu peringkat keempat di dunia. Sementara jumlah tertinggi dipegang oleh negara Amerika Serikat dengan jumlah 110 juta lalu disusul dengan Brasil dan India yang masing-masing memiliki 66 dan 64 juta pengguna (Tirto, 2019).

Kepopuleran Instagram sebagai sosial media dibuktikan juga oleh hasil survei dari WeAreSocial.net dan Hootsuite. Instagram merupakan platform media sosial dengan jumlah pengguna terbanyak ke tujuh di dunia. Total pengguna aktif Instagram di dunia mencapai angka satu milyar pada April 2019 (CNBC Indonesia, 2019).

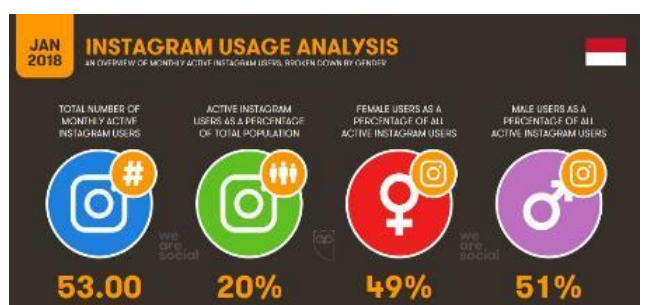

Figure 1. Analisis Pengguna Instagram Sumber : WeAreSocial.net

Kepopuleran Instagram inilah yang dimanfaatkan oleh perusahaan, komunitas, bahkan individu-individu sebagai sarana eksistensi diri maupun sebagai saran menyebarkan informasi. Pemanfaatan tersebut meliputi sebagai sarana publikasi, penyampaian gagasan, mengampanyekan kegiatan atau suatu program, promosi, juga sebagai saran hiburan.

Salah satu penggunaan media sosial Instagram sebagai media publikasi dan kampanye adalah dari Yayasan Peace Generation Indonesia. Peace Generation Indonesia atau yang dikenal dengan nama Peacegen merupakan organisasi yang bergerak di bidang pendidikan perdamaian. Peace Generation Indonesia fokus pada pengembangan pelatihan perdamaian, media pembelajaran perdamaian, dan kegiatan kampanye serta aktivasi konten perdamaian. Peace Generation berkomitmen untuk menyebarkan perdamaian dengan cara-cara yang ceria melalui media kreatif.

Seiring dengan perkembangan zaman dan banyaknya pengguna Instagram, Peace Generation Indonesia menggunakan Instagram sebagai sarana publikasi sekaligus berbagi informasi dan juga sebagai sarana untuk mengampanyekan nilainilai perdamaian dan pendidikan perdamaian. Akun Instagram dari Peace Generation Indonesia (Peacegen) yaitu@peacegenid mengusung konsep penyajian informasi yang singkat dan info grafis dalam setiap postingannya. Postingan ini berisi informasi mengenai nilainilai perdamaian, infografis mengenai konflik, ucapan peringatam hari-hari besar serta berisi kegiatan-kegiatan yang dilakukan oleh Yayasan Peace Generation Indonesia.

Akun media sosial Peace Generation Indonesia terdiri dari Facebook, Twitter, Instagram serta website. Di akun Instagram Peace Generation Indonesia memuat konten mengenai nilai-nilai perdamaian sesuai dengan tujuan dibentuknya organisasi ini yaitu untuk menyebarkan perdamaian, serta kegiatan-kegiatan yang dilakukan 
oleh Peace Generation Indonesia dalam mengampanyekan 12 nilai perdamaian kepada generasi millennials melalui media kreatif yang digunakan. Selain itu ada pula konten lain seperti ucapan hari-hari besar atau quotes yang berasal dari para penggerak perdamaian di dunia, kemudian ada pengalamanpengalaman dari peserta pelatihan mengenai toleransi, serta komik mengenai toleransi.

Akun instagram Peace Generation Indonesia dibuat pada akhir tahun 2014, kemudian mulai aktif mengampanyekan nilai-nilai perdamaian pada tahun 2016 yang sampai saat ini secara konsisten melakukan kampanye lewat media sosial instagram. Hingga saat ini jumlah followers dari akun instagram @peacegenid berjumlah 10,9K pada tanggal 19 November 2019.

Akun Instagram @peacegenid merupakan salah satu bentuk media kampanye, promosi dan publikasi dari organisasi yang berbasis pendidikan. Akun Instagram ini sudah cukup banyak pengikutnya, tetapi dengan banyaknya pengikut di instagram, @peacegenid belum secara kontinyu dalam melakukan pengunggahan konten pada akun media sosial instagram mereka. Jika dibandingkan dengan akun Instagram resmi dari organisasi yang sejenis lainnya seperti akun resmi dari Komunitas Toleransi Indonesia (@toleransi.id) dengan jumlah pengikut sebanyak 37,4k pengikut (19 November 2019) yang dibuat pada Januari 2018 yang sudah dengan konsisten dalam melakukan pengunggahan konten toleransi setiap harinya. Namun, meskipun demikian Peace Generation Indonesia sudah dengan konsisten dalam mempromosikan nilai-nilai perdamaian melalui media sosial.
Tujuan dari dilaksanakannya komunikasi melalui media sosial oleh Tim Creative and Communications Peace Generation Indonesia adalah untuk meningkatkan pemahaman publik terhadap keberagaman dan pentingnya perdamaian. Tujuan dibuatnya media sosial Peace Generation Indonesia selain untuk memberikan pemahaman mengenai nilai-nilai perdamaian dan pentingnya perdamaian, juga untuk mengajak kepada publik khususnya para followers dari instagram @peacegenid untuk melakukan aksi nyata dalam menyebarkan pesan-pesan damai.

$\begin{array}{ccc}\text { Sasaran } & \text { atau target dari } \\ \text { organisasi } & \text { Peace } & \text { Generation }\end{array}$
Indonesia merupakan generasi muda milenial (Generasi Y), sehingga reka bentuk media sosial yang dibuat oleh organisasi ini cukup berwarna dan tidak membosankan. Sebab karakter perilaku generasi milenial ini adalah cenderung berorientasi individual (Satvikadewi \& Kusumaningrum, 2019). Peace Generation Indonesia menyadari bahwa generasi muda sekarang banyak yang sudah mampu menggunakan internet dan biasanya masih sangat labil dalam pencarian jati diri. Kondisi seperti ini dapat dimanfaatkan oleh Peace Generation Indonesia untuk menjadikan generasi muda sekarang sebagai target dari visi dan misi organisasi.

Ericsson mencatat, produk teknologi akan mengikuti gaya hidup masyarakat milenial. Sebab, pergeseran perilaku turut berubah beriringan dengan teknologi. Produk teknologi baru akan muncul sebagai akomodasi perubahan teknologi. Teknologi juga membuat para generasi milenial tersebut mengandalkan media sosial sebagai tempat mendapatkan informasi. Saat ini, media sosial telah menjadi 
platform pelaporan dan sumber berita utama bagi masyarakat.

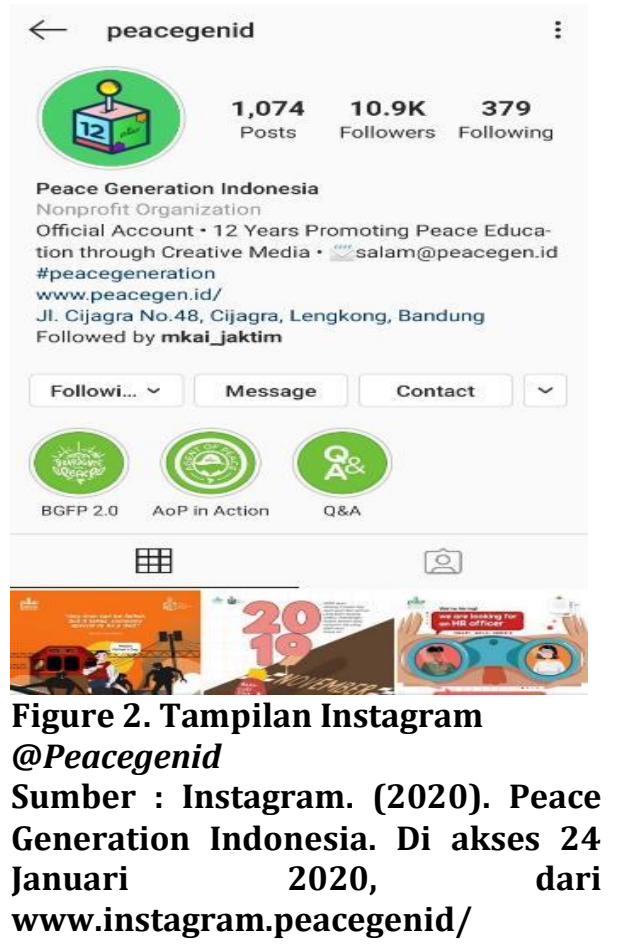

Sebagai media sosial yang memiliki misi untuk menyebarkan nilai-nilai perdamaian, akun Instagram @peacegenid memiliki peranan penting sebagai sarana publikasi dan informasi bagi para pengikutnya serta dalam hal ini organisasi Peace Generation Indonesia mengampanyekan nilainilai perdamaian yang menjadi dasar terbentuknya organisasi ini. Selain itu, Peace Generation Indonesia mempublikasikan kegiatan-kegiatan yang dilakukan oleh organisasi ini dalam mengajak generasi milenial turut serta dalam menyebarkan 12 nilai perdamaian. Yakni hal tersebut ditampilkan dalam bentuk postingan quote-quote dan komik mengenai perdamaian.

Namun, pada kenyataannya informasi yang diberikan oleh akun Instagram @peacegenid belum secara rutin dalam memposting informasi melalui akun instagram. Akun @peacegenid merupakan akun media sosial yang memberikan informasi utamanya bagi publik terutama generasi milenial yang memiliki ketertarikan dengan perdamaian. Akun Instagram @peacegenid belum secara optimal dalam memposting informasi yang berkaitan dengan mengampanyekan nilai-nilai perdamaian.

Strategi yang dilakukan oleh Peace Generation Indonesia berusaha untuk menyasar kaum milenial sebagai target audiens dari akun instagram@peacegenid. Dalam pembuatan strateginya tersebut, Peace Generation Indonesia tentunya melibatkan generasi milenial dalam aksinya. Namun, pada kenyataannya di lapangan strategi yang telah dibuat pun ternyata belum secara efektif dapat menyasar generasi milenial secara keseluruhan. Hal tersebut dirasa oleh Peace Generation Indonesia merupakan efek dari tidak adanya kontinyuitas informasi yang disampaikan melalui media sosial.

Tim creative and communications hanya mengukur keberhasilan media sosial instagram dari matriks peningkatan jumlah followers dan likes dalam bentuk angka. Sedangkan, menurut Lutrell (2015) mengukur dampak media sosial tidak semudah melihat seberapa banyak orang mem-follow maupun orang likes saja. Mengelola media sosial perusahaan, komunitas, ataupun organisasi tidak semudah yang dibayangkan. Hal tersebut juga ditambahkan oleh Lutrell (2015), setiap harinya banyak perusahaan yang gagal dalam media sosial karena perusahaan tidak memahami betul apa itu makna dari media sosial.

Media sosial harus dilihat sebagaimana sebuah perusahaan atau brand secara efektif memanfaatkan masing-masing teknologi tersebut 
untuk menguhubungkan, berinteraksi, dan memupuk hubungan saling percaya dengan orang, tidak hanya sebagai media untuk mengenalkan atau menjual produknya saja. Oleh karena itu, seorang praktisi public relations harus mengerti bagaimana membuat, mengelola, dan memupuk hubungan melalui media sosial.

Tim Creative and

Communications Peace Generation Indonesia mengharapkan penggunaan media sosial Instagram tersebut dapat berdampak besar dan berpengaruh terhadap perilaku dari publiknya. Namun, dikarenakan beberapa hal maka berimbas pada hasil dan tujuan yang telah ditetapkan sebelumnya belum tercapai. Hal ini yang membuat peneliti tertarik untuk meneliti strategi yang dilakukan oleh Peace Generation Indonesia dalam mengampanyekan nilai-nilai perdamaian melalui media sosial Instagram tersebut.

Peneliti mencoba menjelaskan mengenai strategi pengelolaan media sosial yang dilakukan oleh Peace Generation Indonesia. Peneliti akan menggunakan metode penelitian deskriptif untuk menggambarkan seluruh realitas yang terjasi pada Peace Generation Indonesia dalam membuat strategi media sosial dalam mengampanyekan nilai-nilai perdamaian.

Hal tersebut menarik untuk diteliti, mengenai pengelolaan akun media sosial Instagram oleh Tim Creative and Communication Peace Generation Indonesia dalam mempublikasikan dan mengampanyekan nilai-nilai perdamaian.

\section{METODE PENELITIAN}

Penelitian ini menggunakan tipe penulisan deskriptif kualitatif. Pada penelitian deskriptif data yang dikumpulkan adalah berupa katakata, gambar dan bukan angka (Sugiyono, 2012).

Pada penelitian ini, peneliti menentukan informan secara purposive, artinya peneliti menentukan sendiri dengan berbagai pertimbangan tertentu sesuai kriteria yang telah ditentukan oleh peneliti, sehingga peneliti bisa mendapatkan informasi yang dibutuhkan mengenai penelitian ini dari tiap-tiap informan yang telah ditentukan tersebut.

Selanjutnya dinyatakan bahwa sampel sebagai sumber data atau sebagai informan sebaiknya yang memenuhi kriteria sebagai berikut : (1) Mereka yang menguasai atau memahami sesuatu melalui proses enkulturisasi, sehingga itu bukan sekedar diketahui, tetapi juga dihayatinya; (2) Mereka yang tergolong masih sedang berkecimpung atau terlibat pada kegiatan yang tengah diteliti; (3) Mereka yang mempunyai waktu yang memadai untuk dimintai informasi; (4) Mereka yang tidak cenderung menyampaikan informasi hasil "kemasannya" sendiri; dan (5) Mereka yang pada mulanya tergolong "cukup asing" dengan peneliti sehingga lebih menggairahkan untuk dijadikan semacam guru atau narasumber.

Narasumber penelitian ini merupakan orang yang pernyatannya dinilai atau dirasa sesuai dilihat berdasarkan profesinya, sehingga dalam penelitian ini peneliti meneliti narasumber sebagai pengelola akun Instagram @peacegenid yang memegang tanggung jawab melakukan kegiatan Media Sosial. Artinya, pengelola yang bersangkutan tersebut dinilai secara individu yang mewakili lembaga. Adapun narasumber tersebut adalah Ahmad Rijal Hadiyan sebagai Head of Creative and Communications Peace Generation 
Indonesia, Muhammad Rijal Fadhlulloh sebagai Visual Designer, Lindawati Sumpena sebagai Program Officer, dan Nurhayati Syafi'i sebagai Agent of Peace Coordinator Peace Generation Indonesia.

Penelitian ini menggunakan pengumpulan data dengan cara wawancara kepada orang yang terlibat dalam pengelolaan akun media sosial instagram Peace Generation Indonesia dalam hal ini Head of Creative and Communications Peace Generation Indonesia, Visual Designer Peace Generation Indonesia, Program Officer Peace Generation Indonesia, dan Agent of Peace (AoP) Coordinator. Observasi dilakukan yaitu kepada akun media sosial @peacegenid, dan studi kepustakaan berupa buku dan jurnal yang berkaitan dengan penelitian yang sejenis, dan studi kepustakaan berupa buku dan jurnal yang berkaitan dengan penelitia mengenai strategi media sosial.

Proses analisis data kualitatif, setelah mendapatkan data peneliti melakukan validasi data. Teknik validasi data yang peneliti gunakan dalam penelitian ini adalah triangulasi sumber. Triangulasi yang dimaksud adalah triangulasi sumber data. Triangulasi adalah teknik pemeriksaan keabsahan data yang memanfaatkan sesuatu yang lain. Triangulasi dilakukan kepada akademisi yang kompeten dalam bidang sosial media yaitu Rinda Aunillah Sirait, S.I.Kom., M.I.Kom.

\section{HASIL DAN PEMBAHASAN}

Berdasarkan riset dan wawancara yang telah dilakukan peneliti, informan memberikan penjelasan mengenai situasi tersebut. Pengelola media sosial Peace Generation Indonesia menyadari bahwa perkembangan dunia saat ini sudah berubah dan maju ke arah yang serba digital. Perkembangan arus informasi yang semakin lama semakin cepat dan dinamis tersebut, dimanfaatkan oleh Peace Generation Indonesia untuk melakukan kampanye melalui media sosial.

\section{Tahapan Memformulasikan Strategi}

Ahmad Rijal Hadiyan selaku Head of Creative and Communications mengatakan bahwa pada awal dibentuknya Peace Generation Indonesia pada tahun 2007 kegiatan kampanye yang dilakukan yaitu melalui training salah satunya dengan menggunakan modul. Pihaknya menyadari bahwa dunia saat ini telah banyak berkembang ke arah digital, maka dilakukanlah kampanye melalui media sosial. Media sosial yang digunakan oleh Peace Generation Indonesia antara lain Instagram, Twitter, Facebook dan Youtobe.

Media sosial ini menurut Peace Generation Indonesia merupakan salah satu tools untuk berkomunikasi dengan publik. Karena memang untuk sampai ke tahap melakukan aksi perdamaian masih cukup jauh. Selain itu juga, Peace Generation Indonesia memiliki data mengenai adanya penurunan terhadap pendukung Pancasila selama 13 tahun terakhir. Hal tersebut yang memicu terjadinya kekerasan hingga aksi bom bunuh diri sampai pada pendirian negara khilafah akibat adanya penurunan tersebut. Selain itu, semakin maraknya narasi-narasi mengenai radikalisme yang beredar melalu internet. Mulai dari ujaran kebencian, hingga pada ajakan untuk melakukan aksi bom bunuh diri dengan alasan sebagai bagian dari jihad. Sehingga, berdasarkan data yang diperoleh dari Lingkaran Survei Indonesia (LSI) Denny JA terkait adanya peningkatan 
dukungan terhadap didirikannya negara khilafah itu cukup mengkhawatirkan. Dan sasaran dari media dalam mengajak kepada hal-hal yang bersifat radikal tersebut adalah anak muda.

Untuk ini melalui media sosial inilah Peace Generation Indonesia ingin mengenalkan kepada publik khususnya anak muda mengenai narasi perdamaian. Berdasarkan hasil wawancara kepada Lindawati Sumpena yang menyebutkan bahwa tujuan dari dibuatnya media sosial Peace Generation Indonesia guna meng-counter media-media yang cenderung bersifat radikal.

\section{Tahapan Mengimplementasikan Strategi}

\begin{tabular}{ccc}
\multicolumn{2}{c}{ Setelah menetapkan } & situasi, \\
tahapan selanjutnya & adalah
\end{tabular} menentukan tujuan dari penggunaan media sosial Peace Generation Indonesia. Peace Generation Indonesia ingin mengampanyekan 12 nilai perdamaian kepada generasi muda melalui media sosial. Peace Generation Indonesia ingin membangun komunikasi yang baik, menjadi lebih langsung dan personal. Media sosial merupakan bentuk komunikasi secara langsung dan interaktif kepada publik. Di media sosial kita bisa langsung share dan orang-orang bisa langsung membacanya.

Selain itu, media sosial ini salah satu tools untuk menjembatani komunikasi antara komunitas dengan stakeholdersnya. Melalui media sosial inilah perusahaan maupun komunitas berusaha untuk masuk agar dapat menjangkau para stakeholdersnya dengan berkomunikasi secara lebih interaktif dan mengolah pesan yang hendak disampaikan menjadi lebih ringan dan relevan sesuai dengan keadaan saat ini.
Selain itu Rijal Fadhlulloh pun menambahkan bahwa penggunaan media sosial ini tidak akan secara langsung disadari oleh publik untuk mengampanyekan 12 nilai perdamaian, tetapi diperuntukkan untuk membangun awareness kepada publik terkait pentingnya perdamaian ditegakkan. Seperti analisis situasi yang dilakukan, adanya penurunan dukungan terhadap Pancasila dan semakin meningkatnya dukungan untuk mendirikan negara khilafah. Untuk itu melalui media sosial ini ingin menginformasikan mengenai nilai-nilai perdamaian agar publik dapat mengetahui dan menyadari pentingnya perdamaian ditegakkan.

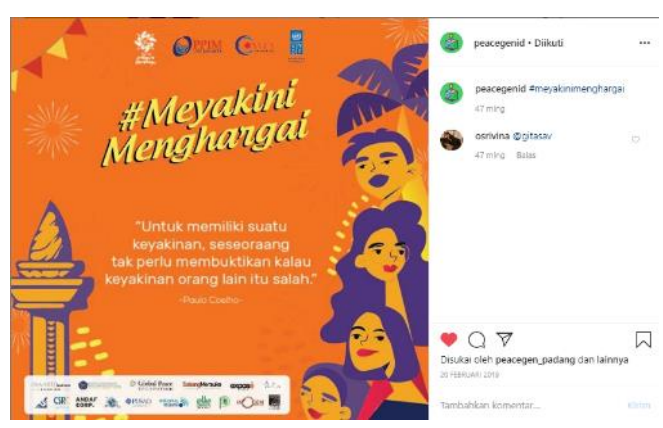

Figure 3. Tujuan Pembuatan Instagram @peacegenid Sumber Data: Instagram. (2020). Peace Generation Indonesia. Di akses 24 Januari 2020, dari www.instagram.peacegenid/

Dalam melihat berhasil tidaknya kampanye yang dilakukan melalui media sosial Instagram tersebut, Peace Generation Indonesia melakukan pemantauan menggunakan aplikasi selama 2 bulan sekali per kampanye yang dilakukan.

Untuk dapat memberikan awareness atau kesadaran kepada publik, Peace Generation Indonesia membuka kemungkinan untuk masyarakat dari berbagai lapisan. Namun, dalam hal ini Peace Generation Indonesia menyadari bahwa generasi muda-lah yang cukup 
tepat untuk dijadikan sebagai target audiens untuk mengampanyekan nilai-nilai perdamaian, karena generasi muda merupakan agent of change termasuk dalam menyebarkan nilai-nilai perdamaian.

Target audiens dari media sosial Instagram Peace Generation Indonesia sendiri sebagian besar adalah kaum Millenials. Menurut pernyataan Ahmad Rijal Hadiyan, target audiens ini dipertimbangkan dari banyaknya kaum millennials yang menggunakan Instagram dalam aktivitasnya. Saat ini, orang-orang yang berusia 40 tahun ke bawah banyak yang menggunakan Instagram.

Dari pernyataan yang dipaparkan oleh para informan, dapat diketahui bahwa yang menjadi target audiens dari media sosial Instagram Peace Generation Indonesia adalah kaum millennials. Dalam menentukan target audiens tersebut, Peace Generation Indonesia menggunakan data dari BPS (Badan Pusat Statistik) pada tahun 2018 yang menunjukkan bahwa sebanyak $23,95 \%$ penduduk Indonesia adalah kelompok millennials. Atau hampir seperlima dari penduduk Indonesia merupakan kelompok millennials.

Setelah penetapan usia tersebut, Peace Generation Indonesia selanjutnya menyasar ke arah geografis atau tempat tinggal. Secara geografis, target audiens media sosial Instagram Peace Generation Indonesia adalah mereka yang tinggal atau berdomisili di kota-kota besar seperti Jakarta, Bandung, Surabaya, Medan, Yogyakarta, Malang, Makassar dan Semarang.

Strategi yang dilakukan oleh Peace Generation Indonesia untuk dapat mengampanyekan nilai-nilai perdamaian yaitu melalui : (1) Community Engagement; (2) AoP
(Agent of Peace); (3) Special Event; dan (4) Social Media Activation. Sebelum menentukan strategi untuk media sosial Instagram tersebut, Peace Generation Indonesia melakukan beberapa langkah terlebih dahulu yaitu identifikasi masalah, menentukan masalah, definition, pengumpulan data dan referensi, design, dan production.

Keempat strategi tersebut kemudian dikembangkan menjadi taktik-taktik oleh Program Officer dan Divission Creative and Communications Peace Generation Indonesia. Salah satu strategi yang dilakukan oleh Peace Generation Indonesia dalam mengampanyekan nilai-nilai perdamaian kepada publik, yaitu Community Engagement. Community Engagement yang dilakukan Peace Generation Indonesia diberi nama dengan Frosh Project ID. Frosh Project ID adalah pilot project kerjasama Peace Generation dengan institusi kampus dan Lembaga riset independen yang menyasar mahasiswa tahun pertama di Bandung.

Program tersebut berangkat dari kesadaran pentingnya membekali mahasiswa baru dengan kemampuan berpikir kritis dan karakter damai. Kedua hal tersebut dapat membentuk individu yang memiliki resiliensi untuk menjalani kehidupan kampus dan paska kuliah. Dalam strategi ini, lebih menginformasikan mengenai kegiatan Frosh ID mulai dari perencanaan hingga pada program tersebut dilaksanakan. Tujuannya adalah agar publik mengetahui bahwa masih banyaknya kelompok yang peduli dengan perdamaian. 


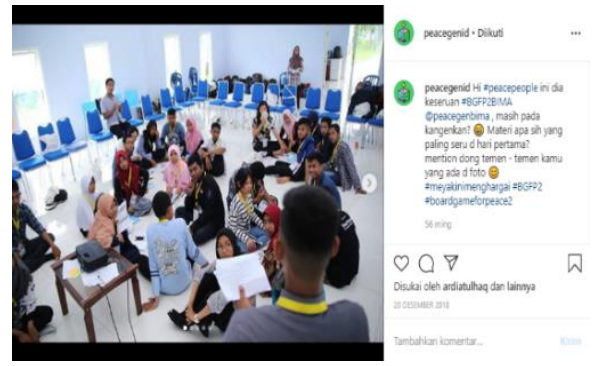

Figure 4. Strategi Community Engagement melalui Boardgame

Sumber Data: Instagram. (2020). Peace Generation Indonesia. Di akses 24 Januari 2020, dari www.instagram.peacegenid/

Strategi selanjutnya yaitu AoP (Agent of Peace) yang merupakan istilah untuk orang yang sudah mengikuti training atau pembelajaran 12 Nilai Dasar Perdamaian Peace Generation . Agent of Peace tersebut mengajarkan dan menyebarkan nilai perdamaian di sekolah dan komunitas mereka. Lindawati Sumpena menjelaskan bahwa Agent of Peacelah yang menjadi ujung tombak Peace Generation Indonesia dalam menebarkan benih perdamaian di Indonesia. Konten-konten yang diposting berkaitan dengan AoP yakni mengenai berbagai kegiatan yang dilakukan oleh AoP di berbagai kota, cerita unik mengenai AoP yang bertujuan untuk menginspirasi publik terkait aksi perdamaian.

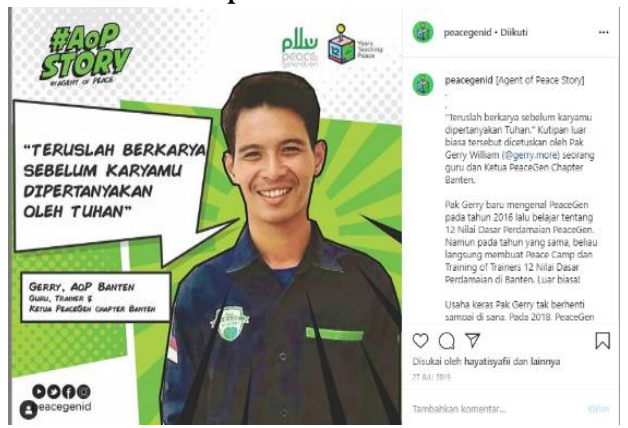

Figure 5. Strategi Agent of Peace Sumber Data: Instagram. (2020). Peace Generation Indonesia. Di akses 24 Januari 2020, dari www.instagram.peacegenid/
Selanjutnya untuk Special Event yang dilakukan yaitu seminar pendidikan, Board Game For Peace (BGFP), Training For Peace, dan Festival For Peace. Setiap kegiatan yang dilakukan oleh Peace Generation Indonesia diposting melalui Instagram @peacegenid dengan tujuan memberikan kesadaran kepada publik mengenai pentingnya perdamaian.

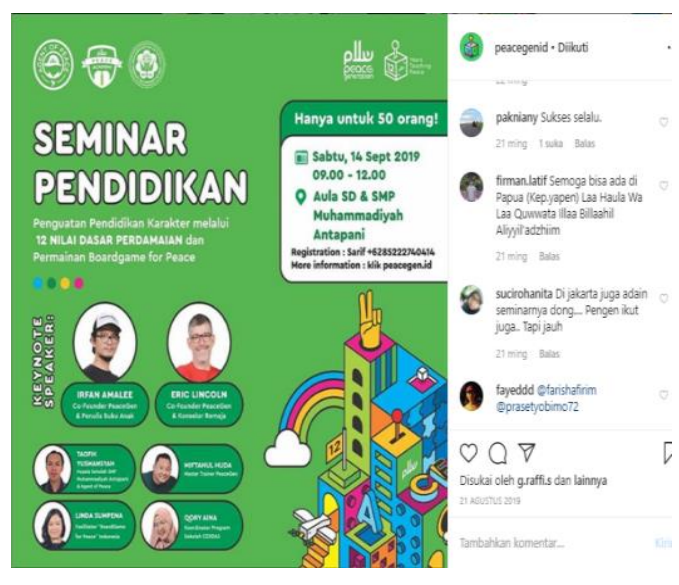

Figure 6. Strategi Special Event Sumber Data: Instagram. (2020). Peace Generation Indonesia. Di akses 24 Januari 2020, dari www.instagram.peacegenid/

Kemudian untuk Social Media Activation adalah strategi untuk melibatkan followers dari Instagram @peacegenid. Tujuannya supaya terjalin komunikasi yang baik antara media sosial Instagram Peace Generation Indonesia dengan followers. Selain itu, dapat juga melihat seberapa besar pengaruh yang selama ini dikampanyekan oleh media sosial Instagram @peacegenid. 


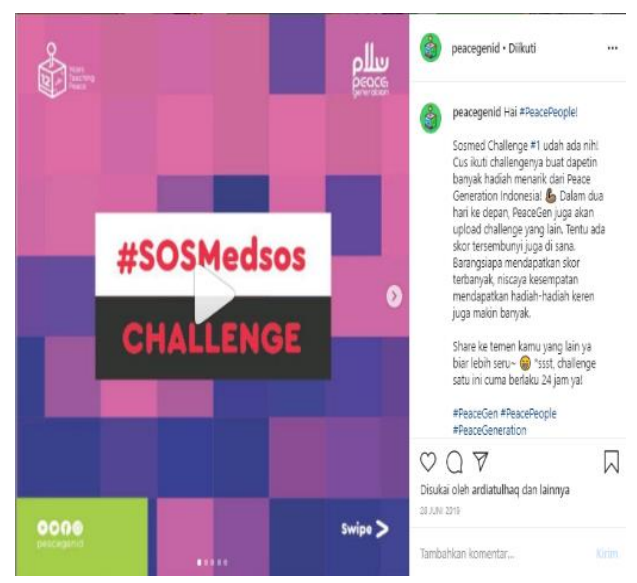

Figure 7. Strategi Social Media Activation

Sumber Data: Instagram. (2020). Peace Generation Indonesia. Di akses 24 Januari 2020, dari www.instagram.peacegenid/

Pemilihan saluran media sosial yang tepat juga perlu diperhatikan secara jelas dengan riset yang dilakukan oleh Peace Generation Indonesia. Menurut Peace Generation Indonesia, Instagram merupakan salah satu media sosial yang tepat untuk mendukung tujuan dari Peace Generation Indonesia dalam mengampanyekan nilai-nilai perdamaian. Melalui pengelolaan media sosial yang tepat secara tidak langsung dapat mengubah hubungan sosial di masyarakat (Prasanti, 2016).

Taktik media sosial yang dibuat oleh Peace Generation merupakan turunan dari strategi yang ditetapkan sebelumnya. Community engagement, Agent of Peace, Special Event, dan Social Media Activation dikomunikasikan melalui salah satu media sosial yang digunakan oleh Peace Generation Indonesia yaitu Instagram. Strategi pertama, community engagement. Pada community engagement ini merupakan bentuk kerjasama dengan institusi kampus dan lembaga riset independen yang menyasar mahasiswa tahun pertama di
Bandung. Kegiatan yang diberi nama dengan Frosh Project ID ini sedang berjalan di dua kampus, ITB dan UPI. Program ini menggunakan metode peer mentoring selama satu tahun dengan melibatkan kakak tingkat sebagai mentor. Pada strategi ini, dilakukan dengan bentuk games mengenai perdamaian. Games tersebut menggunakan media yang bernama board game.

Selanjutnya, untuk strategi AoP (Agent of Peace) ini bentuknya yaitu pengenalan Peace Generation Indonesia, pengenalan 12 nilai perdamaian melalui narasi dan games, dan juga cerita unik dari setiap Agent of Peace di berbagai kota. Kemudian untuk strategi special event terbagi ke dalam dua bentuk yaitu seminar perdamaian dan training mengenai perdamaian.

Dalam proses pelaksanaan penggunaan media sosial, Ahmad Rijal Hadiyan mengatakan yang paling awal dilakukan oleh Peace Generation Indonesia adalah identifikasi masalah. Dari identifikasi masalah tersebut, didapatkan bahwa saat ini publik khususnya generasi millennials masih belum aware terhadap perdamaian. Penyusunan perencanaan konten dilakukan dimana Divisi Creative and Communications membagi konten selanjutnya menyusun topik yang akan dibahas setiap waktunya. Peace Generation Indonesia belum ada waktu posting yang ditentukan, karena hal tersebut disesuaikan dengan Divisi Program Officer dalam mengadakan kegiatan.

$$
\text { Ahmad Rijal Hadiyan }
$$
menjelaskan, setelah membuat perencanaan konten dan mengetahui masalah dari hasil identifikasi, lalu Tim Creative and Communications mencari bahan yang tepat untuk bisa diolah yang kemudian diposting di Instagram. Untuk pembuatan konten 
sendiri, Tim Creative and Communications membuat draft dalam waktu kurang lebih 1 bulan. Bahasa yang digunakan dalam media sosial Instagram Peace Generation Indonesia yaitu informal karena disesuaikan dengan target audiens yaitu generasi muda atau kelompok milenial.

Selain itu, dalam memberikan jawaban dari setiap komentar yang diberikan followers terhadap konten yang diposting, Tim Creative and Communications langsung membalasnya apabila komentar tersebut bersifat membangun atau bersifat positif. Apabila komentar yang muncul berupa complain, tim biasa mendiskusikannya terlebih dahulu lalu setelah itu membalasnya sesuai dengan hasil yang telah didiskusikan sebelumnya.

Selanjutnya, Muhammad Rijal Fadhlulloh menjelaskan dalam setiap konten yang diposting berisi informasi-informasi yang informatif dan persuasif. Nilai-nilai perdamaian yang diinformasikan kepada publik dijabarkan melalui postinganpostingan yang dikemas lebih ringan dan disajikan dengan design yang beragam. Nilai-nilai perdamaian tersebut yaitu : (1) Menerima diri sendiri; (2) Menghapus prasangka; (3) Keragaman etnik; (4) Perbedaan agama; (5) Perbedaan gender; (6) Perbedaan status sosial; (7) Perbedaan kelompok; (8) Merayakan keberagaman; (9) Memahami konflik; (10) Menolak kekerasan; Mengakui kesalahan; dan Memaafkan.

$$
\text { Ahmad Rijal Hadiyan }
$$
menjelaskan bahwa akun Instagram @peacegenid dibuat pada tahun 2015 dan mulai aktif memposting pada tahun 2016. Pada tahun tersebut, Peace Generation Indonesia menyadari bahwa Instagram sangat popular di kalangan masyarakarat khususnya di kalangan millennials. Hal tersebut yang mendorong Peace Generation Indonesia untuk menggunakan Instagram dalam mengampanyekan nilai-nilai perdamaian.

Instagram sendiri memiliki fitur hashtag, sehingga tim Creative and Communications memanfaatkan hal tersebut untuk menarik opini publik pada setiap postingan mereka. Dalam penggunaan hashtag tersebut, tim sebelumnya melakukan diskusi terlebih dahulu untuk selanjutnya menghasilkan hashtag yang disetujui bersama. Tim Creative and Communications akan melakukan posting tersebut sesuai dengan timeline yang telah ditentukan. Kemudian melakukan evaluasi dari setiap postingan tersebut.

\section{Tahapan Mengevaluasi Strategi}

Dari perencanaan yang telah dibuat, untuk mengukur keberhasilan dari strategi yang telah ditetapkan, tim Creative and Communications melihatnya dengan perkembangan followers dalam Instagram, reach dan engagement seperti komentar, likes, maupun share. Menurut tim Creative and Communications, hal tersebut menjadi tolok ukur keberhasilan karena melihat sifat media sosial sendiri yang berarti jika orang mengikuti atau follow akun media sosial tersebut berarti ada ketertarikan untuk mengikutinya. 


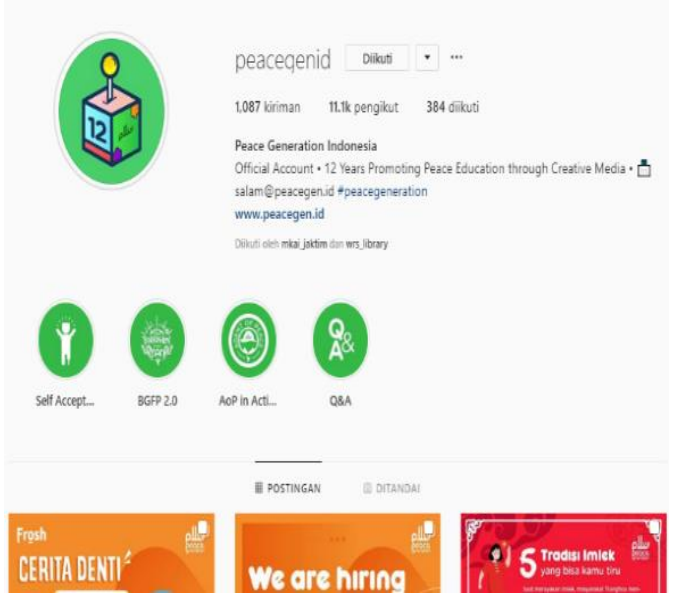

Figure 8. Tampilan Terbaru Instagram @peacegenid

Sumber Data: Instagram. (2020). Peace Generation Indonesia. Di akses 24 Januari 2020, dari www.instagram.peacegenid/

Namun, tim Creative and Communications sampai saat ini belum melaksanakan evaluasi hingga ke tahap followers, seperti kepuasan mengakses atau bahkan perubahan sikap followers. Yang dilakukannya baru pada tahap evaluasi melihat setiap postingan mendapat tanggapan yang positif atau tidak.

Dalam mengukur evaluasi pencapaian tujuan, tim Creative and Communications tidak memiliki pengukuran yang pasti akan setiap strategi yang dilakukan. Tidak hanya itu, tujuan utama yaitu untuk mengampanyekan nilai-nilai perdamaian sendiri belum menunjukkan sesuatu yang signifikan.

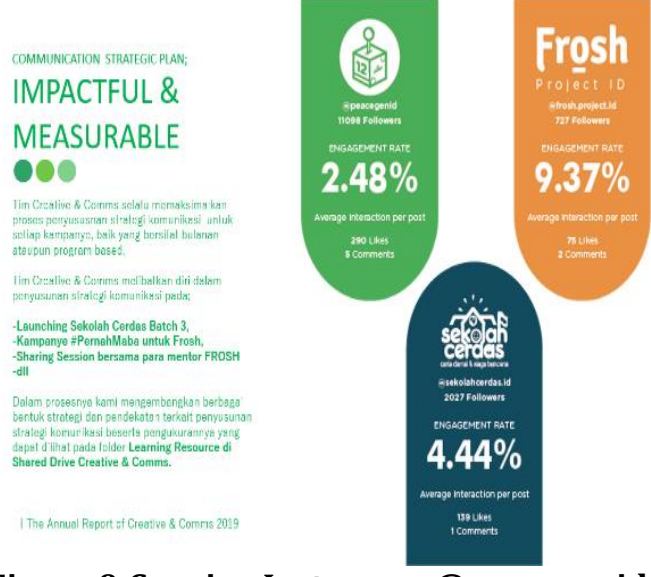

Figure 9.Capaian Instagram @peacegenid Sumber Data : Annual Report of Creative and Communications 2019

Perencanaan waktu media sosial instagram belum memiliki timeline khusus. Hanya saja, untuk penentuan timeline postingannya sendiri secara spesifik memang ditentukan sebulan sebelumnya dimana tim Creative and Communications membuat draft untuk konten-konten apa saja yang ingin diposting dan melihat tanggal agar dapat disesuaikan. Jadwal posting sendiri tidak dilakukan setiap hari, karena disesuaikan dengan keadaan di lapangan dalam identifikasi masalah dan hal teknis lainnya.

Dalam pengelolaan media sosial instagram Peace Generation Indonesia, menurut Ahmad Rijal Hadiyan ada biaya yang dikeluarkan untuk membayar iklan. Selain untuk membayar iklan, tidak ada lagi biaya khusus yang dikeluarkan dalam pengelolaan instagram Peace Generation Indonesia.

Menurut pernyataan yang disampaikan oleh Muhammad Rijal Fadhlulloh, Peace Generation Indonesia belum sampai pada menggunakan influencer atau buzzer dalam pengelolaan instagram maupun 
media sosial lainnya. Pengelolaan media sosial Peace Generation Indonesia dipegang oleh tim Creative and Communication.

Seluruh kegiatan yang berhubungan dengan pengelolaan media sosial Peace Generation Indonesia dikelola sepenuhnya oleh Peace Generation Indonesia secara mandiri tanpa menggunakan bantuan dari pihak eksternal. Sementara anggaran yang dikeluarkan untuk media sosial, Peace Generation Indonesia membayar untuk biaya iklan saja.

Berdasarkan penjelasan Luttrell (2015), pada tahap penetapan situasi ini organisasi menjabarkan hal-hal apa saja yang hendak dicapai oleh organisasi. Tujuan yang valid tidak dapat dirumuskan tanpa pemahaman yang jelas mengenai situasi yang ingin dikembangkan menggunakan media sosial. Organisasi harus memahami situasi mengapa menggunakan media sosial itu diperlukan. Keadaan seperti apa yang membuat organisasi tertarik dan merasa harus menggunakan media sosial sebagai platform.

Smith (2004) menjelaskan bahwa situasi merupakan sebuah keadaan yang sedang dihadapi oleh organisasi. Situasi juga dapat dikatakan mirip dengan pemetaan masalah. Tanpa adanya penetapan situasi yang jelas, organisasi tidak akan dapat melakukan penelitian yang efisien atau mendefinisikan tujuan komunikasi yang ingin dicapai pada proses penetapan tujuan.

Teknologi internet merupakan saluran yang sangat digandrungi oleh publik saat ini. Setiap orang mencari informasi apapun saat ini melalui satu jaringan, yakni internet. Melalui internet, kita dapat menjangkau informasi apapun dengan tanpa terkendala oleh jarak dan waktu. Hal tersebut sesuai dengan E-PR yang dikemukakan oleh Onggo pada tahun 2014 bahwa E-PR merupakan inisiatif Public Relations yang menggunakan media internet sebagai sarana publikasinya (Onggo, 2014).

Ribuan one-to-one relations dapat dibangun secara simultan lewat media internet karena sifatnya yang interaktif. Internet merupakan sarana untuk membangun relations yang ampuh bagi suatu dunia bisnis maupun organisasi non-profit. Internet menuntut para pelaku Public Relations agar dapat memanfaatkan media online. Hal ini tidak dapat dihindari, apalagi kalau perusahaan sudah memiliki situs web atau bahkan sudah menggunakan e-mail. Kalau keberadaan perusahaan maupun organisasi sudah diekspos lewat internet, jangan tanggung-tanggung, karena hal itu akan dapat mempengaruhi persepsi publik terhadap perusahaan.

Media sosial dipilih sebagai tools yang paling tepat saat ini, karena berdasarkan keterangan dari informan, hampir semua orang menggunakan media sosial. Berdasarkan data dari We Are Social, saat ini pengguna internet di Indonesia mencapai 88,1 juta pengguna, dimana 79 juta diantaranya merupakan pengguna media sosial aktif. Angka yang tidak mengherankan, mengingat Indonesia merupakan salah satu negara teraktif di media sosial.

Milenium atau yang lebih akrab disebut dengan generasi millennials paling sering digunakan untuk menggambarkan generasi yang tumbuh subur pada kepuasan instan melalui teknologi, menghabiskan terlalu banyak waktu di media sosial dan malas di tempat kerja. Generasi ini digambarkan sebagai generasi petualang yang lebih suka melakukan 
perjalanan daripada menabung untuk perumahan, untuk makan di luar daripada untuk memasak di rumah, dan untuk menghabiskan uang smartphone terbaru daripada menyimpannya di bank. Cara milenium mengonsumsi berita dan informasi berpusat pada ponsel mereka dan jalan mereka menuju penemuan lebih banyak bernuansa dan bervariasi dari yang dibayangkan beberapa orang.

Aktivitas generasi millennials beralih ke internet untuk meningkatkan produktivitas mereka, dari menggunakan aplikasi produktivitas, merencanakan menggunakan peta dan kalender online hingga berkomunikasi melalui aplikasi chatting. Millennials juga sangat terlibat dengan media sosial dan aplikasi messenger untuk menjaga hubungan dengan kenalan mereka. Generasi ini selalu ingin mengikuti informasi.

Sekitar $\quad 78 \% \quad$ generasi millennials menggunakan internet untuk mencari berita atau hanya untuk menjelajahi internet dan mendapatkan pengetahuan baru. Sebagian besar, generasi millennials menghabiskan sekitar 4,3 jam per hari untuk menggunakan internet dan rata-rata, mereka menghabiskan sekitar Rp 98.000, - untuk penggunaan internet mereka per bulan.

Fenomena radikalisme masih menjadi isu yang menarik bagi sarjana politik nasional dan internasional. Mempertimbangkan peningkatan teknologi dan globalisasi, kelompokkelompok radikal menyesuaikan diri gerakan mereka, mereka meninggalkan metode tradisional dan mencari lebih banyak yang modern. Proses radikalisasi, melalui media online dan narasi radikal, sangat efektif untuk mempengaruhi dan merekrut pemuda.

Masalah terorisme adalah masalah yang kompleks. Oleh karena itu, multi-pendekatan untuk masalah ini sangat penting. Karena peningkatan teknologi, gerakan kelompok teroris telah bermetamorfosis. Dari cara-cara yang bersifat tradisional, saat ini telah bergeser ke metode yang lebih modern. Kelompok-kelompok teroris beradaptasi dalam hal upaya dan pengaruh untuk merekrut pemuda sebanyak mungkin.

Banyak peneliti yang telah meneliti tentang pola dan tindakan terorisme baru, beberapa penelitian mengungkapkan hal itu kelompok teroris telah menggunakan internet sebagai media baru untuk membawa mereka pada tindakan radikalisme. Beberapa penelitian menunjukkan bahwa teroris menggunakan media internet untuk menyebarkan propaganda, mengumpulkan dana dan mencuci uang, merekrut dan melatih anggota, berkomunikasi dan berkonspirasi, meluncurkan serangan ketika pemerintah berusaha untuk melawan dan menangkap mereka secara ortodoks (Weimann, 2006).

Peace Generation Indonesia atau lebih dikenal dengan PeaceGen yang merupakan organisasi nirlaba yang bergerak di bidang pendidikan perdamaian dengan fokus pada pengembangan metode dan pembelajaran media dengan cara yang kreatif dan inovatif. Menanggapi kondisi tersebut, Peace Generation Indonesia yang telah berdiri selama 12 tahun, berusaha tetap konsisten dalam memerangi radikalisme khususnya melalui media sosial.

Jika mengacu pada konsep yang dipaparkan oleh Regina Luttrell, maka Peace Generation Indonesia sudah mengimplementasikan tahapan 
penetapan situasi penggunaan media sosial dengan baik. Peace Generation Indonesia dapat menjelaskan apa saja keadaan yang melatarbelakangi pembuatan media sosial Peace Generation Indonesia berserta alasannya.

Dalam implementasinya, pemilihan media sosial sebagai sarana Komunikasi dan informasi terutama bagi kegiatan promosi tidak terlepas dari target sasaran yang dituju oleh lembaga selain tentu saja ketersediaan pengelola dan juga dana untuk menjalankan komunikasi di media sosial tersebut (Gumilar, 2015). Melalui penyampaian pesan di Instagram, lembaga/perusahaan ingin mengedukasi publik melalui postingan foto dan video yang diunggah melalui instagram. Apalagi saat ini instagram merupakan media sosial yang sedang digandrungi oleh sebagian besar publik di seluruh dunia. Selain itu, instagram juga merupakan media dimana publik dapat melakukan komunikasi dua arah dengan perusahaan maupun instansi melalui fitur komentar yang ada pada instagram.

Menurut pendapat Rinda Aunillah Sirait sebagai triangulator pada penelitian ini, mengatakan bahwa penetapan situasi yang dilakukan oleh Peace Generation Indonesia sudah tepat, hanya saja isu yang diangkat bukan merupakan isu yang populer di kalangan anak muda.

Setelah mengetahui situasi yang terjadi di lapangan, tahapan selanjutnya yang harus dilakukan oleh perusahaan maupun instansi yaitu melakukan penetapan tujuan dari penggunaan media sosial. Penentuan tujuan merupakan hal yang krusial karena tanpa adanya tujuan, maka strategi dan taktik yang dibuat tidak akan memiliki arah yang jelas.
Tujuan dari Peace Generation Indonesia dalam menggunakan media sosial Instagram yaitu untuk menyebarkan nilai-nilai perdamaian kepada publik. Selain itu, juga untuk meningkatkan awareness mengenai perdamaian kepada publik.

Berdasarkan penjelasan yang dikemukakan oleh informan dari Peace Generation Indonesia, bahwa media sosial instagram Peace Generation Indonesia ingin mengampanyekan nilai-nilai perdamaian kepada publik khususnya yang target sasarannya. Selain itu, media sosial Peace Generation Indonesia juga ingin memberikan awareness kepada publik mengenai perdamaian. Menurut keterangan yang diberikan oleh informan, masih banyaknya terjadi konflik di lapangan dan hal tersebut masih menyerang generasi millennials yang menjadi target sasarannya. Peace Generation Indonesia memanfaatkan tools yang ada pada media sosial Instagram, Peace Generation Indonesia dapat mengunggah konten berupa event yang akan diselenggarakan oleh Peace Generation Indonesia, komik mengenai perdamaian, pengalaman mengenai pengalaman seseorang, serta ucapan hari-hari besar maupun hari-hari bersejarah.

Menanggapi penetapan tujuan yang dilakukan oleh Peace Generation Indonesia, Rinda Aunillah Sirait mengatakan bahwa penetapan tujuan yang dibuat sudah cukup tepat, jika melihat dari target audiens media sosial Peace Generation Indonesia. Hanya saja, Rinda menyayangkan bahwa kalau strategi menyebarkan pesan di media sosial Peace Generation Indonesia belum cukup tepat.

Berdasarkan tujuan yang ingin dicapai oleh Peace Generation Indonesia, media sosial instagram 
@peacegenid menargetkan generasi millennials atau generasi muda sebagai tergat audiens dari media sosial instagram mereka. Melalui media sosial instagram, Peace Generation Indonesia ingin memberikan pengetahui kepada generasi muda mengenai pentingnya perdamaian dan mengajak mereka untuk melakukan aksi nyata yang berhubungan dengan perdamaian.

Walaupun perusahaan atau instansi telah memiliki target sendiri, tetapi dalam media sosial tetap harus ditujukan pada target publik yang lebih spesifik. Akan lebih mudah untuk berinteraksi dengan publik jika perusahaan dapat memahami demografi yang sesuai dengan ketertarikan perusahaan. Apakah perusahaan telah berfokus pada area yang sesuai, upaya media sosial harus diarahkan secara langsung tergatung pada audiens yang spesifik. Dalam menentukan publiknya, perusahaan harus benar-benar memahami demografi publik yang diinginkannya (Lutrell, 2015).

Jika ditinjau dari konsep yang dipaparkan oleh Regina Lutrell, Peace Generation Indonesia sudah dapat mengimplementasikan penetapan audiens pada media sosial dengan baik. Meskipun dalam penetapan target audiens tersebut tidak dilakukan riset terlebih dahulu. Dalam hal ini, Peace Generation Indonesia sudah dikatakan dalam menetapkan target audiens sudah cukup spesifik.

Strategi dibuat untuk mendukung tercapainya tujuan yang sudah ditetapkan sebelumnya. Strategi yang dibuat oleh Peace Generation Indonsia dilakukan dan disesuaikan dengan tujuan dari penggunaan media sosial itu sendiri yaitu media sosial untuk mengampanyekan nilai-nilai perdamaian dan menambah awareness publik terhadap pentingnya perdamaian.

Pada tahapan ini, Public Relations menjelaskan bagaimana dan mengapa berbagai komponen kampanye akan mencapai tujuan yang telah ditetapkan perusahaan atau institusi. Guidelines dan key message merupakan hal yang paling sering dimasukkan ke dalam bagian ini (Lutrell, 2015). Terdapat empat strategi yang dilakukan oleh Peace Generation Indonesia dalam media sosial instagram. Pertama, community engagement yaitu bekerja sama dengan organisasi Pendidikan dengan mengadakan kegiatan yang terkait dengan nilai-nilai perdamaian. Pada media sosial instagram melakukan pengunggahan konten yang berupa $e$ poster kegiatan tersebut untuk mengajak audiens supaya ikut bergabung dalam kegiatan tersebut. Selanjutnya, membuat story atau live pada instagram pada saat kegiatan tersebut berlangsung. Strategi yang kedua yaitu Agent of Peace (AoP), informasi yang memuat mengenai cerita (story) dari Agent of Peace di lapangan. Akun instagram @peacegenid memuat konten mengenai cerita dari Agent of Peace di lapangan yang bertujuan untuk memberikan inspirasi serta motivasi kepada audiens. Selanjutnya strategi ketiga yaitu Special Event, event atau kegiatan yang dilakukan untuk menyebarkan nilai-nilai perdamaian yang dikemas dalam bentuk kegiatan yang skalanya lebih besar dan umum. Pada instagramnya diunggah mengenai e-poster kegiatan tersebut dan dibuat story serta live pada saat kegiatan tersebut berlangsung. Strategi keempat yaitu social media activation. Strategi ini dibuat untuk menjalin komunikasi dengan para followers. Pada strategi keempat ini dibuat kegiatan social media challenge 
yang melibatkan para followers untuk ikut gabung dengan kegiatan tersebut. Dari sana dapat dilihat seberapa antusias followers yang mengikuti challenge tersebut dan seberapa jauh kampanye yang dilakukan Peace Generation Indonesia melalui instagram dapat berdampak para followers.

Sebelumnya Peace Generation Indonesia telah menjelaskan hal-hal yang menjadi pertimbangan dalam menggunakan instagram. Diantaranya yaitu instagram dapat menceritakan sebuah peristiwa melalui gambar atau video yang disertai caption. Interaksi yang terjadi di instagram berlangsung dengan sangat cepat. Pada instagram dapat dilakukan perhitungan statistik dari jumlah followers dan likes pada setiap konten yang diposting, serta instagram memiliki fitur berupa live dan stories yang dapat mempermudah Peace Generation Indonesia dalam melakukan broadcast acara serta untuk menunjukkan eksistensi dari Peace Generation Indonesia.

Taktik merupakan penjabaran dari strategi yang telah disusun atau langkah-langkah yang digunakan untuk menjalankan strategi. Agar strategi yang telah dibuat dapat berjalan dengan baik diperlukan adanya taktik untuk mencapai keberhasilan dari strategi itu sendiri.

Taktik merupakan cara yang digunakan untuk mencapai tujuan yang telah ditetapkan oleh perusahaan atau komunitas. Taktik telah dibagi menjadi beberapa area sosial media. Dalam media sosial taktik yang digunakan yaitu SoMe : Share (berbagi), Optimize (optimalisasi), Manage (pengaturan), dan Engage (pengikutsertaan) (Lutrell, 2015).

Saat ini Peace Generation Indonesia belum menggunakan influencer untuk menyebarkan informasi yang akan disampaikan melalui media sosial mereka. Influencer memiliki peran yang cukup baik dalam menyebarkan informasi agar pesan yang disampaikan dapt disebarkan kepada audiens yang lebih luas.

Taktik yang dilakukan oleh Peace Generation Indonesia dinilai masih kurang optimal oleh Rinda Aunillah selaku triangulator. Dalam menggunakan media sosial perlu adanya interaksi yang baik dengan followers-nya karena media sosial digunakan untuk berinteraksi langsung antara perusahaan atau komunitas dengan audiens yang menjadi target sasaran.

Menurut yang disampaikan oleh informan, Peace Generation Indonesia belum memiliki timeline yang pasti dalam pembuatan maupun pengunggahan konten untuk media sosial instagram mereka. Sejauh ini jadwal postingan yang pasti hanya untuk pengunggahan e-poster mengenai peringatan hari besar atau libur nasional. Konten lain seperti event yang dilakukan oleh Tim Program Officer dibuat kondisional menyesuaikan dengan event yang akan dilakukan. Proses pembuatan design hingga pada waktu posting dilakukan selama 1 bulan. Lutrell (2015) mengatakan bahawa tujuan, kompleksitas, dan waktu dari kampanye akan menentukan timeline yang dibuat. Waktu yang dibuat pada timeline berbeda-beda disesuaikan dengan kebutuhan perusahaan.

Berdasarkan penjelasan yang dikemukakan oleh Regina Luttrell di atas, Peace Generation Indonesia belum dapat mengimplementasikan tahapan pembuatan timeline dengan baik. Menurut yang disampaikan oleh informan, pada awalnya Peace Generation Indonesia memiliki target untuk memposting konten pada 
media sosial instagram itu minimal dalam kurun waktu satu minggu ada 3 konten yang diunggah. Namun, pada kenyataannya target tersebut ternyata tidak dapat terpenuhi karena memang kurangnya sumber daya manusia yang dapat mengelola media sosial Peace Generation Indonesia.

Dalam mengelola media sosial Peace Generation Indonesia, saat ini belum ada anggaran khusus yang dikeluarkan untuk media sosial. Tetapi, baru ada biaya pasang iklan dan itupun belum secara konsisten dilakukan. Informan mengatakan bahwa Peace Generation Indonesia belum mengeluarkan biaya secara khusus untuk pengelolaan media sosial. Adapun biaya yang baru dikeluarkan untuk membayar iklan dan hal itupun belum dilakukan secara konsisten.

Lutrell (2015) menjelaskan bahwa setiap perencanaan media sosial memerlukan anggaran (budgeting). Perusahaan ingin mengetahui semua anggaran yang berkaitan dengan kampanye. Anggaran harus mempertimbangkan antara waktu karyawan dan biaya tidak terduga. Alokasikan setidaknya $10 \%$ dari anggaran untuk biaya tidak terduga.

Berdasarkan pemaparan dari Regina Lutrell tersebut, maka dapat dikatakan bahwa Peace Generation Indonesia belum menerapkan tahapan budgeting dalam menjalankan aktivitas media sosialnya dengan baik. Hal ini dikarenakan saat ini belum adanya sumber daya manusia (SDM) yang secara khusus mengelola media sosial Yayasan Peace Generation Indonesia, sehingga belum ada anggaran khusus yang dibuat untuk mendukung atau menjalankan aktivitas media sosial.

\section{KESIMPULAN}

Penetapan situasi (situation statement) yang dilakukan oleh Peace Generation Indonesia yaitu saat ini dalam perencanaan media sosial instagram sudah cukup tepat, dan hal tersebut berdasarkan hasil survei yang dilakukan oleh lembaga-lembaga resmi.

Penetapan tujuan yang dilakukan oleh Peace Generation Indonesia yaitu mengampanyekan nilai-nilai perdamaian kepada publik dalam upaya untuk menambah awareness publik terhadap perdamaian.

Target audiens yang ditetapkan oleh Peace Generation Indonesia pada media sosial instagram mereka yaitu laki-laki dan perempuan generasi milenial dengan rentang usia 17 - 38 tahun yang berada di kota-kota besar seperti Jakarta, Bandung, Surabaya, Malang, Makassar, Medan, dan Yogyakarta.

Strategi yang dilakukan oleh Peace Generation Indonesia yaitu dengan menggabungkan kegiatan offline yang dilakukan oleh Tim Program Officer Peace Generation Indonesia.

Taktik yang digunakan dalam perencanaan media sosial Peace Generation Indonesia yaitu mengidentifikasi masalah yang berada di lapangan, didiskusikan dan diproses untuk menjadi konten yang dapat diposting di Instagram.

Dalam tahapan timeline, Peace Generation Indonesia tidak memiliki timeline khusus dalam mengatur media sosial instagram, tetapi dilakukan berdasarkan pada saat hari-hari besar atau libur nasional atau sebanyak seminggu 3 kali postingan.

Tahap budgeting, Peace Generation Indonesia belum memiliki 
anggaran khusus untuk media sosial mereka.

\section{DAFTAR PUSTAKA}

Abadi, Hidayat Surya.(2019). Media sosial dan antitesis jurnalisme. Jurnal Spektrum Komunikasi, 7 (1), hal.17-29. https://doi.org/10.37826/spe ktrum.v7i1.26

Gumilar, Gumgum.(2015). Pemanfaatan Instgram sebagai sarana promosi oleh pengelola industri kreatif fashion di kota Bandung. Jurnal Ilmu Politik dan Komunikasi, 5 (2), 78-84.

Kristiyono, J. (2015). Budaya Internet: Perkembangan Teknologi Informasi Dan Komunikasi Dalam Mendukung Penggunaan Media Di Masyarakat. Scriptura, 5(1), 23-30.

Luttrell, R. (2015). Social media : how to engage, share, and connect. Maryland: The Rowman \& Littlefield Publishing Group, Inc.

Onggo, Bob Julius. (2004). Cyber Public Relations: Strategi Membangun dan Mempertahankan Merek Global di Era Globalisasi Lewat Media Online. Jakarta: PT. Gramedia.

Prasanti, Ditha.(2016). Perubahan media komunikasi dalam pola komunikasi keluarga di era digital. Jurnal Commed, 1 (1), hal.69-81.

Satvikadewi, A.A.I.P \& Kusumaningrum, H. (2019). Profil psikografis \& penggunaan media pada kelompok milenial pengunjung kebun binatang Surabaya. Jurnal Spektrum Komunikasi, 7 (2), hal.15-28. https://doi.org/10.37826/spe ktrum.v7i2.32

Sitanggang, A. (2019). Konstruksi Makna Iklan "Gojek Mempersembahkan: Cerdikiawan". Jurnal Spektrum Komunikasi, 7(2), 48-63. https://doi.org/10.37826/spe ktrum.v7i2.45

Sugiyono.(2012). Metode Penelitian Kualitatif Kuantitatif. Bandung: Alfabeta.

Smith, Ronald D. 2004. Strategic Planning for Public Relations. London. Lawrence Erlbaum Associatses, Publishers.

Weinmann, G. (2006). Terror on the Internet: The New Arena, The New Challenges.

https://tekno.kompas.com/read/201 9/05/16/03260037/apjiijumlah-pengguna-internet-diindonesia-tembus-171-juta-jiwa Diakses pada tanggal 30 Oktober 2019 pukul 09.45 WIB.

https://tirto.id/pengguna-facebookinstagram-di-indonesiaterbanyak-ke-4-di-dunia-ee8n Diakses pada tanggal 30 Oktober 2019 pukul 10.05 WIB

https://www.cnbcindonesia.com/tec h/20190314125824-3760635/instagram-error-berapajumlah-penggunanya-di-ri Diakses pada tanggal 30 Oktober 2019 pukul 10.12 WIB.

Instagram Peace Generation Indonesia.

https://www.instagram.peacege nid/

Website Peace Generation Indonesia. https://www.peacegen.id/

Diakses pada tanggal 15 November 2019 pukul 12.18 WIB 